науково-практичної конференції (Хмельницький, 15 травня 2019 р). Хмельницький: ХГПА, 2019. С. 137-143.

3. Філь Анастасія. Мовний аспект концептів життя-смерть у збірці «Палімпсести» Василя Стуса. Загальна та прикладна лінгвістика y колі антропоцентричних наук: матеріали Всеукраїнської науковопрактичної конференції студентів та молодих учених (м. Миколаїв, 2 квітня 2021 р.). Миколаїв: СПД Румянцева Г. В., 2021. С. 131-135.

4. Філь Анастасія. Дослідження функцій неповних речень у романі Івана Багряного. Науковий вісник. Хмельницький: ХГПА. 2020. Вип. 2. С. 7-10.

5. Шершун Уляна. Сучасні підходи до формування лексичної компетентності на уроках української мови. Філологічні студії: збірник наукових статей слухачів магістратури спеціальності 014 Середня освіта (Українська мова і література) за матеріалами дипломних робітна здобуття другого (магістерського) рівня вищої освіти. Хмельницький: Вид-во ХГПА, 2020. С. 86-89.

DOI https://doi.org/10.30525/978-9934-26-114-5-63

\title{
ПЕРСПЕКТИВИ ВИКОРИСТАННЯ ДОСВІДУ ПІДГОТОВКИ МАЙБУТНІХ УЧИТЕЛІВ ДО НАДАННЯ ФАСИЛІТАТИВНОЇ ПЕДАГОГІЧНОЇ ПІДТРИМКИ СІМЕЙ У НОРВЕГІЇ
}

\author{
Трухан $\Gamma$. В. \\ аспірант кафедри освітології та інноваційної педагогіки \\ Харківський начіональний педагогічний університет \\ імені Г. С. Сковороди \\ м. Харків, Украӥна
}

Переживаючи демократичні перетворення, українське суспільство звертається до пошуку раціональних шляхів формування особистості нової фундації, яка володіє компетентностями, необхідними для успішної реалізації в світовому суспільстві. Умови, що створюються громадою для розвитку дитини в освітніх установах системи, $\epsilon$ визначальним фактором формування іï особистісних якостей і можливостей. Процес модернізації освіти передбачає створення системи, що відповідає викликам сучасності, де педагог виступає фасилітатором навчального процесу. Слід зазначити, що ефективність процесів перетворення галузі освіти може бути забезпечено за умови створення 
єдиного виховного простору «навчальний заклад - сім'я - суспільство» $[1$, c. 24]. Саме тому набуває актуальності проблема підготовки фахівців до фасилітативної взаємодії з сім'єю. Оскільки процес соціалізації людини починається в родині, сімейне неблагополуччя негативно позначається на формуванні особистості дитини. Враховуючи, гуманістичну спрямованість процесу модернізації сучасної системи освіти ії показником є розширення сфери педагогічної підтримки батьків і сім’ї в цілому.

Для вирішення найважливіших проблем вітчизняної освіти доцільно звернутися до корисних педагогічних теорій, методів та прийомів, накопичених розвиненими зарубіжними країнами. С цієї позицій досвід норвезької педагогіки може надати неоціненну допомогу в проектуванні і побудові стратегій підготовки майбутніх вчителів до надання фасилітативної педагогічної підтримки сімей. Вибір зумовлений тим, що сфера освіти Норвезького Королівства егалітарна та має гуманістичну спрямованість.

Аналіз наукової літератури 3 зазначеного питання дає підставу стверджувати, що незважаючи на багатогранність напрямків вивченням розвитку освітньої галузі Норвегії сучасними дослідниками, недостатньо вивченими залишаються питання підготовки майбутніх учителів до підтримки і взаємодії з сім'єю. Так, дослідження норвезької системи освіти проводили І. Берньє, Г. Васьківська, І. Іванюк, К. Карлсен та інш.; специфіка реформ освіти розглянуті в напрацюваннях Г. Ноканнеса та Н. Вишневської; проблеми дошкільного виховання розкриті у роботах Н. Макарової. Цікавими для нашого наукового пошуку є доробки О. Смельянової, Т. Логвинеко, В. Семілетко, О. Огієнко, в яких висвітлено деякі аспекти підготовки норвезьких вчителів.

Система освіти Норвегії відкрита та динамічна. ÏÏ розвиток відбувається 3 урахуванням того, що вчителі та учні різні, і що вони повинні мати можливість розвинути свої сильні сторони. Якісна й адаптована освіта на ранніх етапах навчального курсу і постійний розвиток компетентності вчителів і керівників шкіл $є$ центральними елементами державної політики в галузі освіти [2, с. 9].

Норвезькі науковці Paul Stephens, Chris Kyriacouв, Finn Egil Tønnessen впевнені, педагогічна освіта має бути новаторською, орієнтованою на розвиток і адаптованою. Нові національні і міжнародні знання про школу i педагогічну освіту, а також зміни в школі i суспільстві повинні сформувати основу для освіти. Це вимагає, щоб педагогічні навчальні заклади створювали хороші можливості для професійних дискусій і взаємодії з професійною сферою. Щоб 
забезпечити реалізацію очікувань суспільства щодо школи, необхідно, щоб вчителі добре розуміли свою роль і значення школи в суспільстві і щоб вони виконували свою роль відповідно до нормативними документами школи [2, с. 10].

Спрощено обговорення ролі вчителя, на думку Chris Kyriacouв, можна розділити на три основні області: 1) учитель на зустрічах 3 учнями, 2) вчитель як частина професійного співтовариства i 3) учитель на зустрічах з батьками та іншими партнерами. Професія вчителя вимагає здатності співпрацювати і спілкуватися з учнями, батьками та іншими учасниками всередині і за межами школи. 3 точки зору науковця, вчитель повинен добре знати учнів і їх передумови до навчання, вміти добре взаємодіяти з учнями і мати позитивний погляд на потенціал учнів. Крім того, вчитель повинен вносити свій вклад в професійне співтовариство [2, с. 15].

Paul Stephens вказує, що вирішальне значення має здатність вчителів бачити учнів, розуміти їх і використовувати потрібні інструменти на ранній стадії. Щоб посилити роль вчителя і створити методику, яка сприяла б ефективності шкільної освіти, був розроблений розширений педагогічний предмет. Розширення предмету педагогіки дозволяє майбутнім учителям, наряду з отриманням базових навичок, вирішувати соціальні проблеми учнів і інші умови, що перешкоджають навчанню. Вони отримають уявлення про те, як школа у співпраці з батьками може внести свій внесок у вирішення таких проблем. 3 точки зору змісту, предмет складається 3 двох частин: основного матеріалу, загального для всіх типів педагогічної освіти, і частини, призначеної для цільової групи, з якою вчитель повинен працювати [2, с. 17].

J. Caspersen, наголошує, що батьки учнів несуть основну відповідальність за виховання своїх дітей i, отже, несуть відповідальність спільно зі школою. Співпраця між сімїю і школою це взаємна відповідальність, і батьки є важливими гравцями, що підтримують учнів в навчанні та мотивації. Батьки повинні бути інформовані про цілі навчання і про те, як воно організовано. Вони повинні бути знайомі з успішністю і розвитком учня в школі. Батьки різнорідна група 3 різними очікуваннями. Занадто важливо, щоб вчителі чуйно реагували на погляди і знання батьків про своїх власних дітей і щоб вони вносили вклад в забезпечення взаємного і рівноправного співробітництва 3 сім'єю. Деякі учні потребують особливого подальше спостереження, яке вимагає навичок, якими зазвичай не володіють учителя [2, с. 20].

Тому в межах розширеного предмету з педагогіки, майбутні вчителя проходять курс 3 фасилітативного спілкування 3 батьками, який 246 
заохочує терпимість і повагу, сприяє діалогу між людьми 3 різним походженням, переконаннями і сексуальною орієнтацією. Також він сприяє розвитку особистісного аспекту ролі вчителя i вчителя як особистості і учасника професійного колективу. Вчителі повинні мати можливість спілкуватися 3 соціальними явищами за межами школи і разом з іншими відповідальними органами мати компетенцію піклуватися про особливо вразливих дітей, наприклад, про дітей, які піддаються жорстокому поводженню [3, с. 120].

Заняття курсу проходять в форматі тренінгової роботи, завдяки чому студенти виробляють навички фасилітації батьківських груп i фасілітативної підтримки сім’ї. 3 огляду на потребу вчителя в кращому розумінніособистості, вступні заняття курсу орієнтовані на розвиток емпатії [3, с. 124$]$.

Широке використання активних методів навчання в норвезькій системі педагогічної освіти пояснюється прагненням максимально наблизити процес навчання до каджого студента, зробити значущим процес придбання навичок i умінь професійної діяльності, а також стимулювати розвиток особистісних якостей студента, необхідних сучасному педагогу-фасилітатору.

Враховуючи сучасні вимоги до підготовки вітчизняних вчителів 3 надання фасилітативної підтримки сім’ї, ми вважаємо доцільним подальше вивчення досвіду системи освіти Норвегії 3 вирішення цього питання 3 метою впровадження цього досвіду в системи освіти України.

\section{Література:}

1. Концепція Нової української школи: Рішення колегії МОН України від 27.10.2016 №10.: офіц. текст. Київ, 2016. С. 34. URL: https://mon.gov.ua/storage/app/media/zagalna\%20serednya/novaukrainskashkolacompressed.pdf (дата звернення: 13.07.2021).

2. Paul Stephens Finn Egil Tønnessen \& Chris Kyriaco Stavanger University College, Norway; University of York, UK. Teacher training and teacher education inEngland and Norway: a comparative studyof policy goals. 2004. Vol. 22 URL: https://www.academia.edu/25766998/Teacher_ training_and_teacher_education_in_England_and_Norway_a_comparative_s tudy_of_policy_goals (дата звернення: 13.07.2021).

3. Caspersen J. Teachers' and nurses' realisation of job values. Oslo: Senter for profesjonsstudier, Høgskolen i Oslo. 2006. Vol. 168. 